\title{
Para superar a dicotomia entre jornalismo e engajamento político
}

\section{Kamila Bossato Fernandes}

Doutoranda; Universidade do Minho, Braga, Portugal; Universidade Federal do Ceará, Fortaleza, CE, Brasil

kamila.fernandes@gmail.com

RUSSELL, Adrienne. Journalism as activism:

recording media power. Cambridge: Polity,

2016.

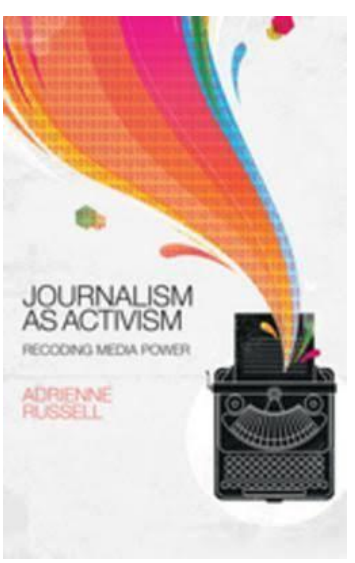

O jornalismo profissional estabeleceu-se historicamente associado a valores que o afastam da tomada de posição, em nome da neutralidade e do equilíbrio, como caminho necessário para alcançar a verdade. Práticas jornalísticas engajadas politicamente, associadas, sobretudo, a uma mídia radical (DOWNING, 2001) ou alternativa (ATTON; HAMILTON, 2008), nunca deixaram de existir, mas foram, em grande medida estigmatizadas como um jornalismo de má qualidade (CARPENTIER, 2011).

As intensas e recentes transformações no ambiente midiático e, como não poderia deixar de ser, no campo do jornalismo, com a inserção de novos atores entre os produtores e com o estabelecimento de novos fluxos de circulação e de apropriação da informação, têm feito com que nos deparemos cada vez mais com práticas jornalísticas que assumem a defesa de certas causas sociais - fenômeno que tensiona ainda mais o campo jornalístico, que segue repleto de incertezas, em um cenário no qual empresas jornalísticas procuram saídas para se manterem relevantes e rentáveis (ANDERSON; BELL; SHIRKY, 2013). 
Em meio a todo esse contexto, a pesquisadora norte-americana Adrienne Russell (2016), em seu livro Journalism as Activism: recording media power, propõe-se a refletir sobre as interligações entre o jornalismo e o ativismo, e também sobre a forma como práticas jornalísticas se têm transformado ao incorporar valores que superam o mero ato de dar "os dois lados da história" e se hibridizam a um engajamento político declarado.

Para tratar do assunto, a autora parte de protestos sociais que ganharam visibilidade midiática ao redor do mundo (Occupy Wall Street, em 2011, People's Climate March, em 2014, e The Day We Fight Back, em 2014, todos nos Estados Unidos), sobretudo pela divulgação em sites de redes sociais, mas não apenas: meios de comunicação tradicionais acabaram por também dar visibilidade às vozes dos ativistas envolvidos.

Entretanto, mais do que abrir espaço às pautas dos ativistas, Russell demonstra o quanto iniciativas midiáticas que nasceram no ambiente dos protestos, como a veiculação em streaming das manifestações, começaram a influenciar práticas jornalísticas. Além disso, também trata sobre como jornalistas que se envolveram com causas sociais passaram a adotar práticas e posicionamentos diferenciados, rejeitando os preceitos da chamada "objetividade jornalística" em nome da prestação de um serviço que consideram mais relevante ao público.

O livro é dividido em cinco capítulos, nos quais a pesquisadora buscou esmiuçar diferentes aspectos da prática jornalística-ativista, como as redes de distribuição do conteúdo informativo, ferramentas utilizadas para produzir e compartilhar o conteúdo, exemplos de práticas lideradas por profissionais da vanguarda midiática e, finalmente, uma discussão sobre o poder dos media, meios de produção e difusão de comunicação social.

Para realizar o livro, a pesquisadora entrevistou, entre 2011 e 2015, 76 pessoas, entre elas jornalistas, mídia-ativistas e desenvolvedores de tecnologia. Para a análise, as entrevistas foram combinadas com coberturas jornalísticas, fóruns de discussão, sites e outros conteúdos publicados sobre os protestos. Em destaque, no quarto capítulo, Russell detalha a prática de quatro profissionais que considera da vanguarda midiática ao inovarem a produção jornalística, assumindo um papel ativista: Bill McKibben (jornalista atuante na cobertura das mudanças climáticas), Glenn Greenwald (conhecido por ter trazido à tona documentos vazados por Edward Snowden), Tim Pool (que inovou ao cobrir o movimento Occupy) e Juliana Rotich (ativista digital que atua na difusão de ferramentas de comunicação para grupos humanitários). 
Mais do que defender um jornalismo ativista, a autora propõe, com essa obra, que se repense o jornalismo não como um modelo fechado, mas como uma prática imersa na disputa de poder, em que vozes antes invisibilizadas passaram a gerar influência, trazendo não só relatos "objetivos", mas afetos e paixões por certas causas - o que se dá pela presença, no ambiente digital, das hackativist sensibilities (sensibilidades hackerativistas, em tradução livre), responsáveis por alterar até mesmo a lógica midiática, que passa a ser pautada pela participação, pelo envolvimento, pelo engajamento - e o jornalismo não teria como ficar fora disso.

\section{Referências}

ANDERSON, Christopher W.; BELL, Emily; SHIRKY, Clay. Jornalismo Pós-Industrial: adaptação aos novos tempos. Revista de Jornalismo ESPM, São Paulo, n. 2, p. 30-88, 2013.

ATTON, Chris; HAMILTON, James. Alternative journalism. Thousand Oaks: Sage Publications, 2008.

CARPENTIER, Nico. Contextualising author-audience convergences: 'new' technologies' claims to increased participation, novelty and uniqueness. Cultural Studies, London, v. 25, n. 4-5, p. 517-533, July/Sept. 2011.

DOWNING, John. Radical media: rebellious communication and social movements. Thousand Oaks: Sage Publications, 2001. 